\title{
Building Collegiate E-Loyalty: The Role Of Perceived Value In The Quality-Loyalty Linkage In Online Higher Education
}

Brandon Kilburn, Ph.D., University of Tennessee Martin, USA Ashley Kilburn, Ph.D., University of Tennessee Martin, USA Dexter Davis, Ed.D., University of Tennessee Martin, USA

\begin{abstract}
E-service quality of online higher education reflects the student's perception of quality of online exchanges across four dimensions: fulfillment, efficiency, system availability and privacy. This study links e-service quality to intentions to remain loyal as mediated by perceived value in an online higher education environment. AMOS is used to examine the structural model based on responses to a student self-report online survey ( $n=127)$. Results indicate a strong causal linkage between e-S-QUAL and Loyalty Intentions as mediated by Perceived Value. Further, the direct linkage between e-S-QUAL and Loyalty Intentions was found to be insignificant, substantiating the proposed full mediation model.
\end{abstract}

Keywords: E-Service Quality; Online Higher Education; Perceived Value; Online Loyalty

\section{INTRODUCTION}

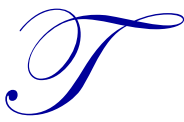

he latest count assessing the number of college students taking at least one course online stands at 7.1 million (Allen \& Seaman, 2014). Additionally, $65.5 \%$ of universities are citing online programs as critical to their long-term strategic plans (Wisloski, 2011). These universities are also becoming increasingly concerned that lower retention rates among students in online classes will temper growth in online instruction (Allen \& Seaman, 2010). Student-website interface dramatically influences their overall student perceptions. The ability of students to understand information exchanged through institutional websites and instructional interfaces become key to their comprehension. University administrators view the development of online education as a requisite for providing the education process on demand, reaching a broader demographic, and sustaining that competitive edge in a competitive education market (Wisloski, 2011). The implementation of a relatively new system like online education is met with a fear of the unknown, and concern over organizational changes and their implications. Concerns over the future are not hindering online educators entering the industry. Approximately $63 \%$ of colleges and universities offering traditional undergraduate courses also offer online degrees (Allen \& Seaman, 2010).

The benefits of an online education can be the ability to eliminate the need for the student to be physically present in the classroom or in visual contact with a teacher at a learning institution. Online education provides virtual study tools and uses course-related graphics and visual aids. Currently over $50 \%$ of U.S. students are returning to education after having worked, or are currently working while pursuing their degree (Hiltz \& Shea, 2005). Online education benefits those students because it is less restrictive on a person's lack of mobility, time constraints, domestic responsibilities, or financial issues.

This study empirically examines the impact of student perceptions regarding e-service quality on their intentions to remain loyal to the online university, as mediated by the students' perceptions of value. The following discussion surrounds the need for closer assessment of general e-service quality in online higher education as it indirectly impacts the likelihood that students will successfully complete their degrees with their current institution, possibly 
increase their frequency or quantity of exchanges with the university, or spread positive word-of-mouth regarding their online collegiate experience.

\section{E-S-QUAL AND PERCEIVED VALUE}

With a growth in online enrollment, additional demands are being placed on technological systems, professorstudent communication and consistency in online delivery of educational goals. Universities are aggressively considering quality control and assessment in the online environment (Abdullah, 2006). Currently, measures of success within the online university center mainly on student retention and program completion. Often, these indicators become measures of activity instead of true measures of the quality of students' educational service (Soutar \& McNeil, 1996). Gauging the e-service quality of online education is about fostering positive change to enhance the learning experience for online students. More importantly, it is vital that universities fully understand the strategic and financial implications of student quality perceptions.

Studies have long shown that high levels of service quality positively influence customer satisfaction (Cronin \& Taylor, 1992; Parasuraman, Zeithaml, \& Berry, 1988) and can provide a competitive advantage. Universities are now concerned with values, skills and abilities of their graduates (Ginsberg, 1991; Lawson, 1992), but also gauging how much their students appreciate their educational experience. Educators are coming under close scrutiny for that perceived quality that they provide to the students. The current system of performance indicators setup by the government that determines funding is opposed by most working within education. The problems are vast in constructing performance indicators in education. One problem is that these indicators become measures of activity instead of true measures of the quality of students' educational service (Soutar \& McNeil, 1996). The provision of education coincides with the indicators but fail to measure anything in a comprehensive way.

Wolfinbarger and Gilly (2003) found that reliability/fulfillment ratings were the strongest predictor of customer satisfaction and quality, and the second strongest predictor of intentions to repurchase at a site. Parasuraman, Zeithaml and Malhotra (2005) suggest that customers' assessment of a website's quality includes not only experiences during their interactions with the site, but also post-interaction service aspects (i.e., fulfillment, returns). The authors' $e$-S-QUAL measure broadly assesses the extent to which a website facilitates efficient and effective shopping, purchasing, and delivery (Parasuraman, et al., 2005) across four dimensions: efficiency, fulfillment, system availability and privacy.

Efficiency is the simplicity and quickness of entering and using a website (Parasuraman, et al., 2005). Efficiency reflects how intuitive a website is to a user. Fulfillment recognizes the extent to which the site's claims about order delivery and item availability are fulfilled (Parasuraman, et al., 2005). Such claims can include billing, product information, having items in stock and delivering what the customer ordered within the designated time frame. Fulfillment may also refer to the ability of the site to meet the user's expectations. The third dimension of e-SQUAL is system availability. System availability reflects the correct technological performance of the institution's website (Parasuraman, et al., 2005). How often a website is unavailable or improperly functioning reflects its system availability. The fourth and final dimension of e-S-QUAL is privacy: the level of safety and protection a student feels while on their university's learning website.

Perceived value in a services setting is a customer's global assessment of utility resulting from a comparison of what a customer expects versus what they experience (Zeithaml, 1988). Customers analyze the difference between their benefits (e.g., quality, convenience (Monroe, 1990)) and costs (monetary and non-monetary (Cronin, Brady \& Hult, 2000; Dodds, Monroe, \& Grewal, 1991; Monroe, 1990). Additionally, e-service quality has been repeatedly linked to perceived value (Santouridis, Trivellas \& Tsimonis, 2012).

Research to date has assessed online higher education in terms of pedagogy, instructor-student collaboration, assignment/project appropriateness, virtual educational delivery and social ramifications of online versus traditional higher education formats (O’Neill, Singh, \& O'Donoghue, 2004; Raj, Walters \& Rashid 2009; Unwin, 2003). Alternatively, universities are increasingly becoming concerned with more global assessments of quality and performance. Institutions of higher education, though imparting knowledge, are after all, businesses. $e$-S-QUAL has shown to be particularly useful when applied to broad business models, like online banking, online bill-pay 
services, and online-only businesses, (i.e. amazon.com, google.com, and online gaming services). The linkage from e-service-quality and perceived value is hypothesized to be positive and direct.

H1: e-service quality is a significant determinant of perceived value.

\section{Perceived Value and Loyalty in Online Higher Education}

e-Loyalty is referred to as the "stickiness" of a customer to an online outlet (Reichheld \& Shefter, 2000). Despite an intial diagnosis that online customers tend to demonstrate lower capacity for loyalty, online customers are actually proving a higher tendency to remain with an online exchange partner despite ease of movement and increased accessibility. We've heard for years (Reichheld \& Sasser, 1990) that the economic benefit of retaining customers in a traditional organization far exceeds the acquisition of new customers. Further, the up-front cost of the purely online customer tends to be higher than the face-to-face customer. Remarkably, however, profits have shown to increase at a much faster rate with purely online customers (Reichheld \& Shefter, 2000). The justification for the promotion of e-loyalty is evident.

Allen and Seaman (2010) reported that approximately $73 \%$ of online universities feel that a focus on increasing retention rates of online students is an "important" area of concern. Therefore, the next chapter of the online university saga will shift the focus from growth strategy to the effective retention and leverage of current learners. Increased usage, benefit maximization, preference, concise evoked sets, positive word of mouth, and decreased costs to serve become probable with continue-use customers (Reichheld \& Sasser, 1990).

In higher education settings, high perceived value and resulting increased loyalty intentions will materialize as reenrollment the following semester, encouraging fellow peers to enroll, or perhaps alumni encouraging their children to seek education at their alma mater. Approaches to achieving e-loyalty are multiple and varied to include trust, perceived value, customer satisfaction (Oliver, 1980; Parasuraman, et al.,, 2005; Sugiati, Thoyib, Hadiwidjoyo, \& Setiawan, 2013). Perceived value is posited as a mediator of the e-service quality-loyalty linkage.

Students' intentions to remain loyal capture their attitude or behavioral intent to remain a customer of a particular service provider through repeat purchases (Hallowell, 1996; Jones \& Sasser, 1995). The relationship between service quality and increased profitability can provide a competitive advantage by repeat sales, positive word-ofmouth, customer loyalty, and competitive product differentiation (Brown \& Swartz 1989; Chao, Lee \& Ho, 2009; Cronin \& Taylor, 1992; Parasuraman, et al., 1988). Research has determined that loyalty is an outcome of service provider image, perceived service quality, switching costs, as well as satisfaction (Aydin \& Ozer, 2005). Substantial research also links service quality perceptions to service customers' loyalty intentions through the mediating effect of perceived value (Parasuraman, et al., 2005; Swaid \& Wigand, 2012).

H2: Perceived value mediates the e-service quality $\rightarrow$ loyalty linkage.

Existing research has framed perceived value as a significant mediator from indicator variables and loyalty intentions (Parasuraman, et al., 2005; Swaid \& Wigand, 2012). This study will substantiate those findings by hypothesizing that there will be a weak, non-significant direct linkage from e-service quality and loyalty.

H3: e-service quality and loyalty will be significantly, directly related.

\section{METHOD AND ANALYSIS}

\section{Measures}

Parasuraman, et al.'s (2005) e-S-QUAL measure broadly assesses the extent to which a website facilitates efficient and effective shopping, purchasing, and delivery (Parasuraman, et al., 2005). The 20-item scale has four dimensions: efficiency (i.e., Is navigation easy? Can transactions be completed quickly? Does the website load fast?), fulfillment (i.e., Are orders delivered as promised and offers described truthfully?), system availability (i.e., Is the site always available? Does it launch right away?), and privacy (i.e., Information privacy is protected and 
personal information is not shared with other sites). Responses were given based on a 5-point scale (1-strongly disagree to 5-strongly agree) based on Parasuraman et al.'s (2005) four dimensions of e-service quality. The composite e-S-QUAL scale's reliability is sufficient $(\alpha=.954)$ (Nunnally, 1978).

Perceived value gauges students' aggregate impressions of the institutions' price, convenience and control (Parasuraman, et al., 2005). The perceived value scale had sufficient reliability $(\alpha=.890)$ (Nunnally, 1978). Finally, the study measures the loyalty intentions among current students through a five-item behavioral loyalty scale developed by Zeithaml, Berry, and Parasuraman (1996). The loyalty intentions scale demonstrates sufficient reliability in this study $(\alpha=.960)$ (Nunnally, 1978).

\section{Data Collection}

Data was collected from undergraduate and graduate students at a 4-year click and mortar university located in the Southeastern US. The regionally-accredited state university offers undergraduate degrees as well as Master degrees online. A self-report online survey was administered using Qualtrics. A total of 146 students out of 941 students taking at least one online course responded to the initial survey request. 19 of the survey responses were partially completed and subsequently dropped from the final sample $(n=127)$. This sample size exceeds the minimum standard of 5 respondents per item needed to conduct factor analysis (Stevens, 1996). Approximately $70 \%$ of the sample indicated taking solely online classes for their purely online degree, while the remainder took a mixture of both live and online classes to complete their degrees. The majority of students ranged in age between 23 and 47. Student classification consisted of primarily juniors, seniors, and those in a graduate program at $22 \%, 33 \%$, and $18 \%$, respectively.

\section{Assessment of e-S-QUAL}

The structural integrity of $e-S-Q U A L$ was assessed by performing Confirmatory Factor Analysis using Maximum Likelihood in AMOS as suggested by Parasuraman, et al., (2005) (Figure 1). The CFA of the 2nd- order measurement model suggests that each of the four dimensions load significantly onto e-S-QUAL with loadings exceeding .40. More specifically, the four factors account for approximately $81 \%$ of the variance in $e-S-Q U A L$. Discriminant validity among each of the four factors was also assessed by examining the interfactor correlations (.45 to .69), indicating that each factor is distinct from the others. The standardized regression coefficients, or construct loadings, of the four factors to the second-order construct of $e-S-Q U A L$ are largely acceptable $(>.70)$ with one exception of the privacy factor (.45).

Figure 1. Proposed Structural Model

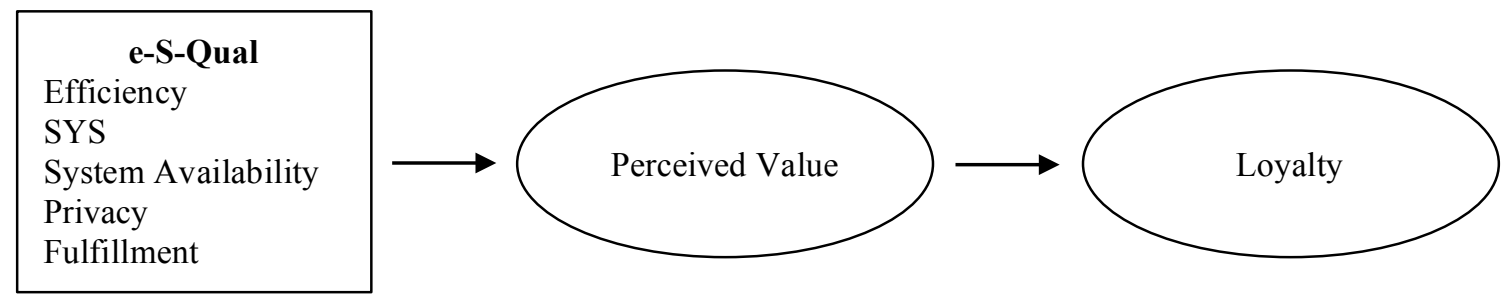

The 22-item $e-S$ - $Q U A L$ measurement model indicates good fit of the model with the data $\lambda^{2}=608.337$. Further, the goodness of fit indices indicate that the data fits the model well $(\mathrm{CFI}=.862, \mathrm{NFI}=.821$, RFI $=.795)$. RMSEA is slightly high (.14), although it is found acceptable given the standards of Browne and Cudeck (1993). Reliability of the composite scale is satisfactorily high at $(\alpha=.954)$ exceeding Nunnally's .70 standard (1978). The coefficient alphas for each of the e-S-QUAL dimensions range from .914 to .986 . In summary, there is sufficient evidence for convergent and discriminant validities for the e-S-QUAL scale. 


\section{Structural Model}

Structural equation modeling using AMOS was used to assess the structural model (e-S-QUAL $\rightarrow$ Perceived Value $\rightarrow$ Loyalty Intentions). The 2nd-order structural model demonstrated relatively good fit of the data to the model with $\lambda^{2}=1078.891$ (Table 1). Further, the goodness of fit indices indicate that the data fits the model well (CFI = $.828, \mathrm{NFI}=.762, \mathrm{RFI}=.739)$. RMSEA, however, was slightly high, at .13 . The RMSEA finding is acceptable given the standards of Browne and Cudeck (1993). Coincidentally, Parasuraman et al., (2005) also identified a high RMSEA for the e-S-QUAL in their original nomological assessment of the scale. In their study, the authors offered large sample sizes as possible explanation of the high RMSEA. This study's sample size was significantly smaller, and resulted in a slight decrease in RMSEA from .16 to .13.

Table 1. Structural Model Results (Ml)

\begin{tabular}{|c|c|c|c|}
\hline Hypotheses & Sig. & Estimates $^{\text {a } \beta}$ & $\mathbf{R}^{2}$ \\
\hline H1: e-service quality $\rightarrow$ Perceived Value, reject $\mathrm{Ho}$ & .00 & 0.900 & 0.223 \\
\hline H2: Perceived Value $\rightarrow$ Loyalty, reject $\mathrm{Ho}$ & .02 & 0.635 & 0.318 \\
\hline H3: e-service quality $\rightarrow$ Loyalty, fail to reject $\mathrm{Ho}$ & .43 & 0.635 & -- \\
\hline \multicolumn{4}{|l|}{ Goodness of fit statistics: } \\
\hline \multicolumn{4}{|l|}{$\lambda 2=1078.891$, PROB. $\mathrm{LEVEL}=.000$} \\
\hline \multicolumn{4}{|l|}{$d f=370$} \\
\hline \multicolumn{4}{|l|}{$\mathrm{CFI}=.828$} \\
\hline \multicolumn{4}{|l|}{$\mathrm{GFI}=.601$} \\
\hline \multicolumn{4}{|l|}{$\mathrm{AGFI}=.531$} \\
\hline \multicolumn{4}{|l|}{$\mathrm{TLI}=.812$} \\
\hline \multicolumn{4}{|l|}{ RMSEA $=.13$} \\
\hline PCLOSE $=.000$ & & & \\
\hline
\end{tabular}

$\mathrm{a}=$ standardized loadings per Maximum Likelihood model using AMOS

$\mathrm{H} 1$ is supported. H1 states that there is a significant relationship between e-service quality and perceived value (sig. $=.000$; reject null). This finding is expected based on past research. The linkage between e-service quality and perceived value indicates that online users base their assessment of benefits vs. costs on their interaction quality with the website used by the higher education institutions.

Results suggest that H2 is supported (sig. .02) indicating that the hypothesis of perceived value and its positive, direct linkage with loyalty is significant. Further, $\mathrm{H}_{3}$ correctly states that there is evidence that there is no direct linkage between e-service quality and loyalty (sig.=.43; fail to reject null). This finding is as expected given the a priori theory of a mediated relationship between e-service quality and loyalty. The mediated relationship between eservice quality and loyalty intentions by perceived value indicates that the institution's attempts to improve the quality of educational websites as a means of increasing perceived value among students are well-founded. Without movement in the student value equation assessment, an increase in loyalty from investments in service quality improvement will, according to these findings, prove futile.

\section{MANAGERIAL IMPLICATIONS}

Institutions of higher education, whose main objective is to impart knowledge, also happen to be businesses. Currently over $50 \%$ of U.S. students are returning to education after having worked, or are currently working while pursuing their degree (Hiltz \& Shea, 2005). One of the most powerful trends influencing business strategy is service quality (Cronin \& Taylor, 1992; Parasuraman, et al., 1988). Results indicate an extremely strong causal linkage between e-S-QUAL and Loyalty Intentions as mediated by student perceptions of value. Further, the direct linkage between e-S-QUAL and Loyalty Intentions was negative and non-significant. This study provides more substantiation for the proposed full mediation model indicating the strength of the quality-perceived value-loyalty intentions linkage so well substantiated in research.

Universities are aggressively considering quality control and assessment in the online environment (Abdullah, 2006). Currently, measures of success within the online university center mainly on student retention and program 
completion. Universities are increasingly becoming concerned with more global assessments of quality and performance. Institutions of higher education, as discussed herein, are businesses expected to retain their customers, generate income and establish a point of differentiation. Often, these indicators become measures of activity instead of true measures of the quality of students' educational service (Soutar \& McNeil, 1996). Gauging the e-service quality of online education is about fostering positive change to enhance the learning experience for online students. More importantly, it is vital that universities fully understand the strategic and financial implications of student quality perceptions.

\section{ACKNOWLEDGEMENTS}

Partially Funded by Project RITE (Research of Instructional Technology in Education) Grant, University of Tennessee

\section{AUTHOR BIOGRAPHIES}

Dr. Brandon Kilburn is currently an Associate Professor at the University of Tennessee Martin. Dr. Kilburn earned his Ph.D. from the University of Memphis with a major in Management. He has had manuscripts published in Academy of Marketing Studies Journal, and NACE Journal. Dr. Kilburn's research focus is on leadership, organizational communication with emphasis on upward feedback, and followership in organizations

Dr. Ashley Kilburn is currently an Associate Professor at the University of Tennessee Martin. She earned her $\mathrm{Ph} . D$. from the University of Memphis. Dr. Kilburn's major was marketing, with a minor in management. She has had manuscripts published in Academy of Marketing Studies Journal, International Journal of Internet Marketing and Advertising, Services Marketing Quarterly, and NACE Journal. Dr. Kilburn's research stream includes service quality, service delivery, internal market orientation, internal customer orientation.

Dr. Dexter Davis is currently an Assistant Professor at the University of Tennessee Martin. He earned his Ed.D. from United States Sports Academy with a major in Sport Management. Dr. Davis has published in the College Student Journal, Korean Journal of Business Administration, and The Sports Journal. Dr. Davis focuses primarily on Sport Business and experiential learning in higher education.

\section{REFERENCES}

Abdullah, F. (2006). The Development of HEdPERF: A New Measuring Instrument of Service Quality for The Higher Education Sector, International Journal of Consumer Studies, 30 (6), pp. 569-581.

Allen, E. \& Seaman, J. (2010). Growing by Degrees: Online Education in the United States, Sloan Consortium, pp. 1-30, http://www.sloanconsortium.org/publications/survey/pdf/learningondemand.pdf

Allen, E. \& Seaman, J. (2014). Grade change: tracking online education in the United States, Sloan Consortium, pp. 1-45, http://www.onlinelearningsurvey.com/reports/gradechange.pdf

Aydin, S. \& Ozer, G. (2005). The analysis of antecedents of customer loyalty in the turkish mobile telecommunication market, European Journal of Marketing, 39 (7/8), pp. 910-925.

Browne, M. \& Cudeck, R. (1993). Alternative Ways of Assessing Model Fit, in Testing Structural Equation Models, Kenneth A. Bollen and J. Scott Long, eds. Newbury Park, CA: Sage, pp. 136-62.

Brown, S. \& Swartz, T. (1989). A Gap Analysis of Professional Service Quality, Journal of Marketing, 53 (2), pp. 92-98.

Chao, Y., Lee, G. \& Ho, Y. (2009). Customer Loyalty in Virtual Environments: An Empirical Study in e-Bank, AIP Conference Proceedings, 1148(1), pp. 497-500.

Cronin, J. \& Taylor, S. (1992). Measuring Service Quality: A Reexamination and Extension, Journal of Marketing, 56 (July), pp. $55-68$.

Cronin, J., Brady, M. K., \& Hult, G. (2000). Assessing the effects of quality, value, and customer satisfaction on consumer behavioral intentions in service environments, Journal of Retailing, 76, pp. 193-218.

Dodds, W.B., Monroe, K.B., \& Grewal, D. (1991). Effects of price, brand, and store information on buyers' product evaluations, Journal of Marketing Research, 28(3), pp. 307-319.

Hallowell, R. (1996). The relationships of customer satisfaction, customer loyalty, and profitability: an empirical study, International Journal of Service Industry Management, 7(4),pp. 27-42.

Hiltz, S., \& Shea, P. (2005). The student in the online classroom. In S. Hiltz \& R. Goldman (Eds.), Learning together online: Research on asynchronous learning networks (pp. 145-168). Mahwah, NJ: Erlbaum. 
Jones, T. \& Sasser, W. (1995). Why satisfied customers defect, Harvard Business Review, 73(6), pp. 88-99.

Monroe, K. B. (1990). Pricing: Making Profitable Decisions (2nd ed.). New York: McGraw-Hill.

Nunnally, J. C. (1978). Psychometric theory (2nd ed.). New York: McGraw-Hill

O’Neill, K. Singh, G. \& O’Donoghue, J. (2004). Implementing eLearning Programmes for Higher Education: A Review of the Literature Journal of Information Technology Education, p. 3.

Parasuraman, A., Zeithaml, V. \& Berry, L. (1988). SERVQUAL: A Multiple-Item Scale for Measuring Service Quality, Journal of Retailing, 64 (1), pp. 12-40.

Parasuraman, A., Zeithaml, V \& Malhotra, (2005). E-S-QUAL: A Multiple-Item Scale for Assessing Electronic Service Quality, Journal of Service Research, 7(10), pp. 1-21.

Raj, R., Walters, P. \& Rashid, T. (2009). Events Management: An Integrated and Practical Approach, Los Angeles, CA, Sage Publications.

Reichheld, F. F. \& Sasser, Jr., W. E. (1990). Zero defections. Quality comes to services, Harvard Business Review, 68(5), pp. 105-111.

Reichheld, F.F. \& P. Schefter (2000). E-Loyalty: Your Secret Weapon on the Web, Harvard Business Review, 78(4), pp. 105113.

Santouridis, I., Trivellas, P. \& Tsimonis, G. (2012). Using E-S-QUAL to measure internet service quality of commerce web sites in Greece, International Journal of Quality and Service Sciences, 4(1), pp. 86-98.

Soutar, G. \& McNeil, M. (1996). Measuring service quality in a tertiary institution, Journal of Educational Administration, 34 , pp. 72-82.

Stevens, J. (1996). Applied multivariate statistics for the social sciences, Lawrence Erlbaum, Mahwah, NJ.

Swaid, S. \& Wigand, R. (2012). The Effect of perceived Site-to-Store Service Quality on Percieved a Value and Loyalty Intentions in Multichannel Retailing, International Journal of Management, 29 (3).

Unwin, D. (2003). Information support for e-Learning: principles and practice, UK eUniversities Worldwide Summer. In Sajja, P.S. (2008) Enhancing quality in e-Learning by knowledge-based IT support, International Journal of Education and Development using ICT, Vol. 4, No. 1, www.ijedict.dec.uwi.edu

Wisloski, J. (2011). Online Education Study: As Enrollment Rises, Institutions See Online Education as a 'Critical Part' of Growth, Online Education Information, http://www.geteducated.com/online-education-facts-and-statistics/latest-onlinelearning-news-and-research/461-online-education-study-increasing-enrollment

Wolfinbarger, M. \& Gilly, M. (2003). Why Consumers Shop Online, Who They Are, and What they Want, in The Internet Encyclopedia, ed. Hossein Bigdoli, John Wiley (December).

Zeithaml, V. (1988). Customer perceptions of price, quality, and value: a means-end model and synthesis of evidence, Journal of Marketing, 52 (July), pp. 2-22. 
NOTES 